(post-Apollo). This group is clearly intended for the manning of the Apollo Applications Programme where the premium is put on manned supervision of astronomy from orbit. Four of the 11 have research experience in astrophysics.

As a group, the 16 scientist-astronauts now under active training are less stereotyped than the previous 49 jet pilot recruits. They do not average $2 \cdot 3$ children each as before, and their age spread is much widerthe geophysicist of the new group is only 25 and one of the astronomers is already 40 . Dr Garriott, an ionospheric physicist selected in 1965 as one of the first group of scientific astronauts, was in London recently attending the IQSY-COSPAR meeting and renewing acquaintance with the Radioand Space Research Station, Slough, where he had worked for a year before becoming an astronaut candidate. He made it clear that scientists selected were not led to believe that their expertise had been earmarked in advance for a particular mission -quite the contrary. Training, which is a continuous process up to the moment of lift-off, is aimed at broadening scientific experience as well as technical skills-such as piloting jet aircraft. In fact Dr Garriott had come to England from a geological field party in Iceland where some of the volcanic regions are thought to resemble lunar terrains more closely than most terrestrial landscapes.

Of the total tally of 66 astronauts, 56 are on the active list today. An Air Force doctor in the 1965 intake of scientist-astronauts resigned; one of last year's pilot officer recruits was killed in a motor accident in June; three of the regular astronaut groups II and III were killed in aircraft crashes during training; three, including space-walker White, died in this year's tragic Apollo ground-test accident. US Navy Commander Scott Carpenter has just returned to the Navy to pursue his work in "inner space" in the "Man-inthe-Sea" experimental programme, and John Glenn has been seconded to other duties.

\section{Doctorate Production}

THE National Science Foundation of the United States has issued its estimates of scientific manpower for the next decade. On the assumption that the student population will continue to increase at its present rate, the United States will need three hundred and seventy thousand science lecturers and research workers in universities by 1970. It is expected that the percentage of those university workers with $\mathrm{PhD}$ degrees will fall over the next few years, but will return to the present level in the mid seventies. The estimates of those taking the bachelors' and doctors' degrees are as follows:

$\begin{array}{ccl} & \text { Bachelors } & \text { Doctors } \\ 1965 & 238,000 & 12,100 \\ 1970 & 348,000 & 20,000 \\ 1975 & 428,000 & 30.500\end{array}$

Of the newly qualified PhDs of recent years, about 15 per cent were foreign, and the estimates assume that there will be no change in this proportion.

Though the United States will be doubling what the foundation calls its "baccalaureate and doctorate production" in the ten year period, its population is only expected to increase by 18 per cent, to two hundred and thirty million. Alternatively, the progression of the United States towards a nation in mortar boards can be shown by calculating the proportion of babies born in any year who are destined to become science graduates at the age of twenty-one. Of those born in 1944, one in twelve received a B.Se. in 1965. Of those born ten years later, one in nine are expected to graduate in science, and more than one in twenty-nine will acquire a higher degree.

The report gives no indication of how far into the future we may expect the expansion of American education to continue. There are more ways to produce doctorates than by training first class minds; the report says nothing of the maintenance of standards. And if baccalaureate production is to double every decade, as it has done, while population output lags behind, can quality control be stringent?

\section{Missiles for Mao}

The Joint Committee on Atomic Energy of the United States Congress now believes that China will have inter-continental ballistic missiles with nuclear warheads in the early $1970 \mathrm{~s}$. Its report states that there is evidence that the sixth and latest Chinese test device was dropped from an aircraft. The fall-out from the fifth test, details of which were not released by the American Atomic Energy Commission at the time, indicated that uranium-238 was being used as fissionable material, and that the fusion material, tritium, was produced by fission-induced decay from lithium-6. The Chinese therefore seemed to have solved most of the problems of designing fusion bombs by last December, and the committee believes that the yield of the fifth bomb may have been deliberately limited, to keep the fall-out over China to a low level. The explosion of a megaton bomb was fully expected. The first four tests conducted in China took place in October 1964, May 1965, and May and October 1966. The third of these was the largest, the size of the weapon being between two hundred and a thousand kilotons. There is evidence that lithium- 6 was involved in this third bomb, as well as the fifth. The other three were smaller, the first being twenty kilotons, while the other two were slightly larger, in the low intermediate range of between twenty and two hundred kilotons.

Reviewing the French atomic programme in the same report-a strange juxtaposition, since the report is supposed to deal with the effect on United States security of the Chinese weapons-the Committee concluded that France is a long way behind China. It even doubts whether the French will explode a hydrogen bomb in 1968. On the other hand, the French do have a strategic force of Mirage IVs; the Chinese are not known to have a means of delivering their more powerful weapons. China has already developed an intermediate range missile, according to the report, but there are no signs that this is in service. The Chinese are also supposed to be "interested in the development of submarines" armed with long range rockets, though the committee has no knowledge of actual developments.

The report will, no doubt, influence the argument about the development of anti-missile defences in the United States. The committee mentions that the United States will lack defences against a Chinese attack, but does not reveal its views on the establishment of an anti-missile system. Nor is there any discussion in the report of the possible effects of the cultural revolution on Chinese activities. It is difficult 